\title{
Expansion and population dynamics of a non-native invasive species: the 40-year history of American mink colonisation of Poland
}

\author{
Marcin Brzeziński • Michał Żmihorski • Aleksandra Zarzycka • \\ Andrzej Zalewski 1 (D)
}

Received: 21 August 2017/Accepted: 7 September 2018/Published online: 12 September 2018

(C) The Author(s) 2018

\begin{abstract}
The American mink, an invasive mammal introduced to Europe, severely impacts native biodiversity. The history of its invasion has been poorly investigated in central and eastern Europe, and the current variations in densities of mink populations are not well studied, thus making a reduction of its impact difficult. Here we analyse the temporal dynamics and spatial distribution of the American mink population in Poland, which began to establish itself at the beginning of the 1980s and originated from Polish farm escapees and immigrants from Lithuania and Belarus. Mink dispersal started in the north and continued to the south and in 2016 mink occurrence was recorded across ca. $75 \%$ of the country. By about 1997 mink had colonised half of Poland, and in 2016 the only mink-free area was in the south and south-east
\end{abstract}

M. Brzeziński · A. Zarzycka

Faculty of Biology, University of Warsaw, ul.

Miecznikowa 1, 02-096 Warsaw, Poland

\section{M. Żmihorski}

Institute of Nature Conservation, Polish Academy of Sciences, al. A. Mickiewicza 33, 31-120 Kraków, Poland

M. Żmihorski

Department of Ecology, Swedish University of Agricultural Sciences, Box 7044, 75007 Uppsala, Sweden

A. Zalewski (

Mammal Research Institute, Polish Academy of Sciences, ul. Stoczek 1, 17-230 Białowieża, Poland

e-mail: zalewski@ibs.bialowieza.pl of the country. The rate of expansion showed accelerating and decelerating patterns, and reached its maximum 12 years after the beginning of the expansion. Mink farming in western Poland developed rapidly after 2000 and probably influenced acceleration of mink range expansion rates in years 2006-2008. Indices of mink densities showed significant nonlinear change over time since local populations were established and were highest in populations estimated to be 10-15 years old. The prediction of non-native species invasion rates and population dynamics should be incorporated into management actions curbing their negative impact on native fauna.

Keywords Alien species - Neovison vison $\cdot$ Mink farming $\cdot$ Expansion rate $\cdot$ Spread dynamics

\section{Introduction}

Invasive species pose a threat to biodiversity and often contribute to a decrease, or local extinction, of native species (Clavero and García-Berthou 2005; Hilton and Cuthbert 2010). The effective management of invasive species requires data on their expansion rate and density during various stages of expansion (Fraser et al. 2015). Understanding the mechanisms that limit or accelerate rates of range expansion and affect population dynamics during expansion is of key 
importance to predict spread and reduce the negative impacts of invasive species. Early theoretical models describe dispersal as a simple random-diffusion process and assume a linear, constant increase in range over time across a homogeneous landscape in which habitat connectivity is high (Skellam 1951; Okubo and Levin 2002). In some cases such a dispersal pattern has been observed (e.g. Reeves and Usher 1989). However, current more advanced models suggest that heterogeneous landscapes, variable availability of resources, different climate conditions as well as their interaction with invasive species density, influence patterns of range expansion and invasion may periodically accelerate or decelerate (Hastings et al. 2005). Landscape and habitat heterogeneity strongly affect expansion rates across space (Smith et al. 2002; Zalewski et al. 2009), and identifying the environmental conditions that influence expansion is important for managing invasive species populations.

The population density of invasive species usually increases after introduction, and the increase can be accelerated by low intraspecific competition (low density), low interspecific competition, lack of enemies (predators, parasites and diseases), lack of defence mechanisms in native plants and animals (naïve prey), and sometimes by ongoing propagule pressure (continuous introduction of individuals to a new area) (Lockwood et al. 2013). All these factors may cause the density of an invasive species to become high (even higher than in the native range) relatively quickly. Over time, as density increases, density-dependent mechanisms begin to reduce population numbers. Furthermore, in a new area invasive predators intensively exploit resources of naïve prey thus decreasing their availability. Therefore, after the increase, the density of an invasive species should decrease and stabilise. Theoretical modelling can guide future management of alien invasive species (Iordan et al. 2012). However, the theoretical predictions concerning the non-linear density dynamics of invasive species in newly colonised areas require long-term empirical data. Such long-term data are scarce (Simberloff and Gibbons 2004; Aagaard and Lockwood 2016) but they are important to predict the impact of invasive species on ecosystems, to establish management plans and to reduce the negative consequences of the invasion.

The American mink Neovison vison is a non-native invasive mustelid that has colonised vast areas of
Europe. Mink began to disperse across Europe in the first half of the twentieth century and colonised several countries within just a few decades. Since then at least 20 European countries have reported established feral mink populations, founded by mink either released on purpose or which escaped from fur farms (besides the intentional introductions that took place in the former Soviet Union) (Bonesi and Palazon 2007). The history of mink expansion in many European countries is well documented (e.g., Gerell 1967; Smal 1988; Kauhala 1996; Ruiz-Olmo et al. 1997) and in others basic information about colonisation processes is available (e.g., Mickevicius and Baranauskas 1992; Ozolinš̌ and Pilăts 1995). However, the current distribution, population dynamics and densities of mink populations in many European countries are not well studied, and contrasting demographic processes probably occur in different regions (Bonesi and Palazon 2007). These may result from the following factors that affect mink populations in Europe: (a) the development of mink farming (either forbidden, reduced, stable or increasing); (b) the development of control or eradication programmes at different scales and hunting pressure; (c) interspecific competition between mink and other carnivores; (d) decreasing or fluctuating availability of food resources; (e) accumulation of parasites, pathogens and spread of diseases; (g) habitat suitability and its spatial heterogeneity.

In this study we analysed the available data on mink presence and first observation dates collected across Poland as well as the results of our mink trapping to describe the spatio-temporal dynamics of this species in the country over the last 40 years. In Poland, the first mink farms were established in 1928, but farming on a larger scale began in 1953 (Lisiecki and Sławoń 1980). Feral mink in Poland were first reported in the 1980s (Ruprecht et al. 1983), soon after the first mink had been observed in the wild. Up to the end of the 1990 s, i.e. about 20 years after the first wild mink observations, the mink was reported to have colonised half of Poland (Brzeziński and Marzec 2003) and its expansion was correlated with serious declines of several water birds and semi-aquatic mammals (Brzeziński et al. 2010, 2012). Mink colonisation of Poland was initiated both by immigrants from the east (Belarus, Lithuania) and numerous escapees from farms located in Poland. Genetic studies in the first decade of the twentieth-century assigned feral mink in Poland to at least four distinguishable clusters 
(Zalewski et al. 2010), suggesting local mink populations had different origins. It is very likely that extensive development of mink farming in the last two decades in Poland has increased the probability of mink escaping from farms and has led to multiple local introductions.

The goal of our study was to present the course of mink invasion in Poland, characterize factors affecting the rate of range expansion through a variety of landscapes and estimate population density in relation to time since local populations were established. We hypothesized that the rate of range expansion has varied over time and could have accelerated in areas with suitable landscape features (e.g. a high proportion of water bodies), high habitat connectivity (river network) or mink farm abundance. We also predicted that mink density increased over the first stage of expansion and then decreased. Therefore, we expect non-linear expansion both in the rate of range expansion and in the population growth.

\section{Materials and methods}

\section{Questionnaires}

The history of American mink expansion in Poland is based on mink observations in the wild and hunted animals from the early 1980 s to 2016 . The oldest information was published in the 1980s by Ruprecht et al. (1983), Romanowski et al. (1984) and Żurowski and Kammler (1987), and supplemented in the next decade by Ruprecht (1996). These authors gathered information about mink presence in Poland sent to them by hunters, environmentalists, scientists and other people (and occasionally their personal observations). In our database, we used 56 mink records attributed to a certain location and year, and which came from the publications mentioned above. The other group of records comes from questionnaires that were sent to units of the Polish Hunting Association in 1998 (Brzeziński and Marzec 2003). Hunters were asked to answer when and where mink were first recorded in their hunting districts. Questionnaires were returned from 727 hunting units, and 197 of them confirmed the presence of the mink. The next sources of information were questionnaires sent to hunting units, offices of landscape parks, national parks and forest inspectorates in 2016. We obtained 91 positive and 64 negative answers to the question about mink presence and first mink observations. Additionally, we used data from mink trapping conducted in the years 1995-2016 (see below). In total, after rejecting some unreliable information, we possessed 467 records of mink presence or absence up to 2016 and 344 records of the years in which mink were first recorded at locations. These two datasets were used for creating two maps showing the probabilities of occurrence and dates of colonisation.

\section{Mink trapping}

The density indices of feral mink populations in Poland are based on live-trapping conducted in the years 1995-2016. In these years mink were trapped in 57 study sites; 13 of them were large rivers ( $>50 \mathrm{~m}$ wide), 13 medium rivers (20-50 m wide), 21 small rivers $(<20 \mathrm{~m}$ wide) and 10 lakes. Trapping sites were distributed across the whole of Poland. In 42 of them mink were trapped only during one single trapping session and at the rest of them twice (14 sites) or threefold (one site). The total trapping effort was 12,681 trap-nights. In 14 sites mink trapping was unsuccessful and no mink were captured there. Mink were live-trapped in the autumn (November-December), winter (January-February) and spring (MarchApril). Wooden-box or wire-mesh live-traps baited with fresh fish were set at about $500 \mathrm{~m}$ intervals along the shoreline and checked once a day. Captured mink were anaesthetized with Narkamon, marked with incisions on the upper part of the ear, weighed and released at the location of their capture. The only exception was five sites in national parks where captured mink were removed. In each study site a min. of 20 traps were used during each trapping session. The duration of trapping sessions in particular sites and years varied considerably, from 4 to 14 days. For comparing mink density in various study sites we used the index of mink trapping success (number of mink trapped per 100 trap-nights) during the first 4-5 days of trapping only. All mink capture and handling procedures were approved by the Ministry of Environment, Regional Directorate for Environmental Protection and the Local Ethics Committee for Animal Experiments. 
Statistical analysis

First, we visualized the presence/absence of American mink in 467 locations in Poland. For this purpose we used a generalized additive model with a binomial error distribution and logit link (GAM 1) using the 'mgcv' package (Wood 2006) in R ( $\mathrm{R}$ Core Team 2016). We discriminated occupied $(n=344)$ and unoccupied $(n=123)$ locations in Poland by using longitude and latitude fitted with an interaction of thin plate regression splines as explanatory variables. In the model we used the k parameter (indicating the level of spline fit complexity) of the interaction set to 25 , which was the highest value producing a statistically significant interaction (i.e. more complex models were not significant). We visualized GAM 1 by plotting a map of the probability of mink occurrence in Poland.

Second, we performed a generalized additive model (GAM 2) with a Gaussian error distribution and identity link to interpolate the date of first mink record in 344 occupied locations (123 unoccupied locations were excluded). The year of the first record (ranging from 1975 to 2016) was used as a response variable while longitude and latitude fitted with an interaction of splines were explanatory variables. In GAM 2 we considered various levels of smoothing (i.e. different values of the $\mathrm{k}$ parameter) but most of them gave similar results; thus we selected $\mathrm{k}=60$ as the most reliable, although $\mathrm{k}$ values between 40 and 80 were almost identical indicating that the observed pattern is rather weakly dependent on model parameters. Based on GAM 2 we visualized the years of mink colonisation in Poland.

Third, based on GAM 2 we calculated the expected year of first mink occurrence for each square of $2 \times 2$ $\mathrm{km}$ grid superimposed on the study area $(\mathrm{n}=78,129$ grid squares in total). Two landscape parameters (share of aquatic and urban habitats) were also calculated for each square of $2 \times 2-\mathrm{km}$ grid using GIS tools. We calculated the index of range expansion (Arim et al. 2006) as the ln-transformed number of new invaded $2 \times 2-k m$ squares $(\mathrm{N})$ in a given year $(\mathrm{t})$ from previous occupied sites:

$\ln \left(\mathrm{N}_{\mathrm{t}+1} / \sum_{\mathrm{t}-5}^{\mathrm{t}} \mathrm{N}_{\mathrm{t}}\right)$.

Next, we correlated the two measures of range expansion rate (the index of range expansion in a given year and area colonised each year) with the two landscape parameters (share of aquatic and urban habitats) averaged across all grid cells colonised each year. The correlations checked if landscape parameters correspond to expansion rate.

Finally, we investigated how local density index of American mink in a given location has changed over time since colonisation began. For this purpose, we performed generalized additive mixed models (GAMM 3) explaining the density index (number of mink captured per 100 trap-nights) in 81 local populations as a function of the number of years since the mink population was established as predicted by GAM 2. We included the year effect as a random factor fitted with a ridge penalty spline, and water body type (small river $<20 \mathrm{~m}$ wide, medium river 20-50 $\mathrm{m}$ wide, large river $>50 \mathrm{~m}$ wide, lake) and season (autumn, winter, spring) as two fixed effects, to control for possible environmental drivers of density index. We did not predefine the upper limit of the $\mathrm{k}$ parameter (i.e. level of smoothing); thus the generalized cross-validation approach incorporated in the spline function (Wood 2006) was allowed to select the optimal smoothing parameter (i.e. a linear fit was also possible). We used the Gaussian error distribution and identity link in the model.

\section{Results}

\section{Mink distribution}

In 2016 American mink was likely to occur across about $75 \%$ of Poland, and only the most southern and south-eastern regions were not yet occupied by mink (Fig. 1; GAM 1; interaction of longitude and latitude, $d f=24$, Chi square $=36.98 ; p=0.044)$. The area between the two main rivers, the Vistula and Oder, still has a low probability of mink occurrence. This region largely overlaps with the watershed between these two rivers. The date of the first occurrence of mink in Poland showed strong spatial patterning (GAM 2; interaction of longitude and latitude, $d f=59$, $\mathrm{F}=17.69 ; p<0.0001$ ). The first records (before 1980-1985) of the species were from few locations in the north, but almost the entire lowland part of the country was colonised by 2000 (Fig. 2).

During ca. 20 years (from the beginning of the 1980 s to the end of the 1990s) mink invaded over $50 \%$ of Poland. Since that time extensive new areas have 


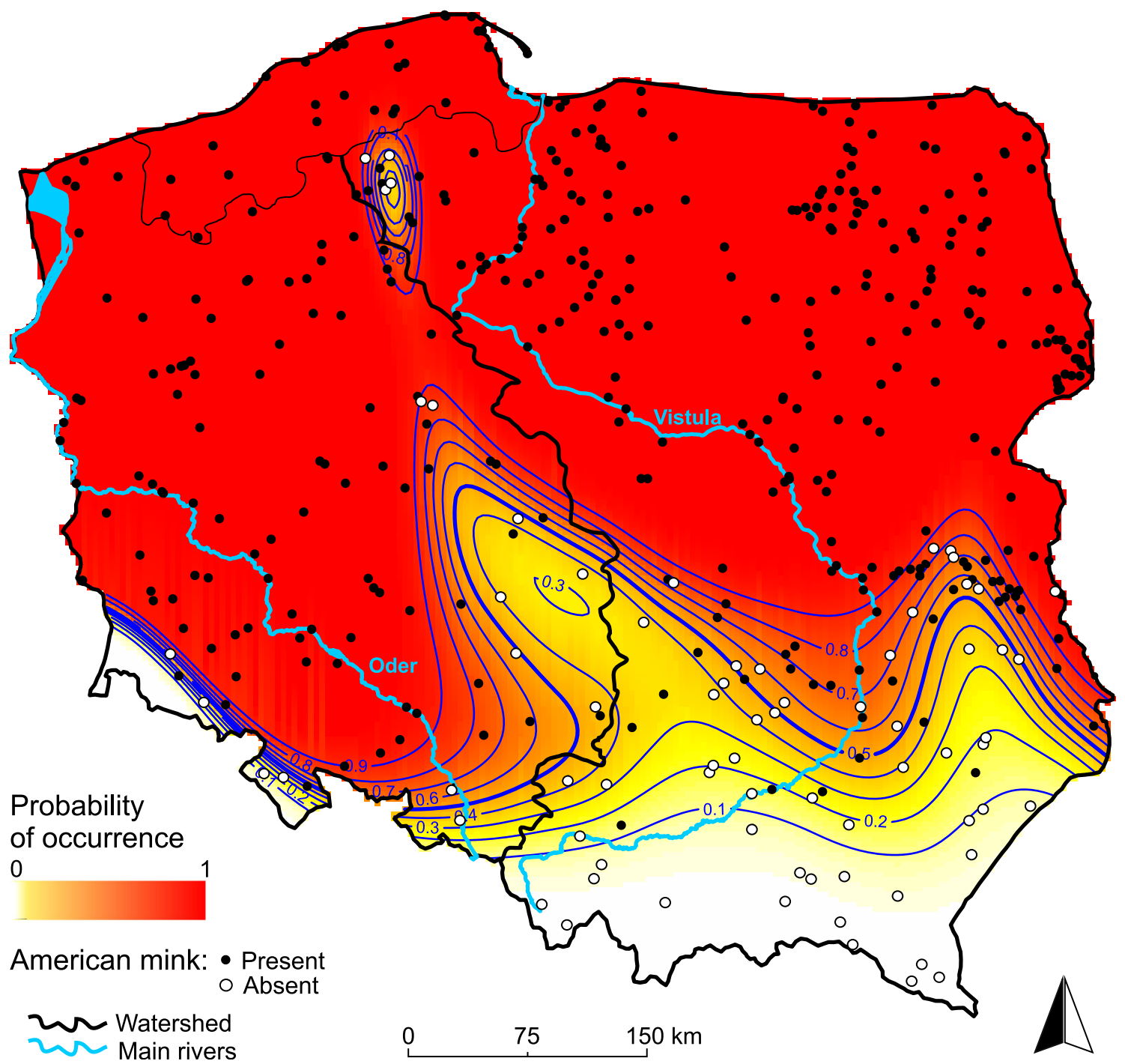

Fig. 1 Probability of occurrence (based on GAM 1, shown with isolines) of the American mink in Poland in 2016. Presence/absence in certain locations $(n=467)$ is shown

been colonised, and the mink population has expanded to the south, upstream of the largest Polish rivers: Vistula and Oder (Fig. 2). The rate of expansion showed an accelerating and decelerating pattern. From 1980 to 1992 the rate of expansion accelerated up to $20,000 \mathrm{~km}^{2}$ per year (Fig. 3a). After this period it decelerated down to about $6000 \mathrm{~km}^{2}$ per year, and again increased in the years 2006-2008 to nearly $14,000 \mathrm{~km}^{2}$ per year and then decreased in the following years to $3000 \mathrm{~km}^{2}$ per year (Fig. 3a). The cumulative area reached $270,000 \mathrm{~km}^{2}$ after 35 years of invasion, which gives about $7700 \mathrm{~km}^{2}$ per year on average. The rate of expansion also showed a variable temporal pattern (peaking around 2008) and was correlated with an increase in pelt production (Fig. 3b).

Both the area colonised each year and the index of range expansion were positively correlated with the share of aquatic habitats within the colonised area (Pearson correlations the share of water habitats logtransformed, $\mathrm{r}=0.39, \quad p=0.005$ and $\mathrm{r}=0.47$, $p=0.006$ respectively). Moreover, the index of rate expansion negatively correlated with the share of urban habitats within the colonised area $(\mathrm{r}=-0.58$, $p<0.001)$. 


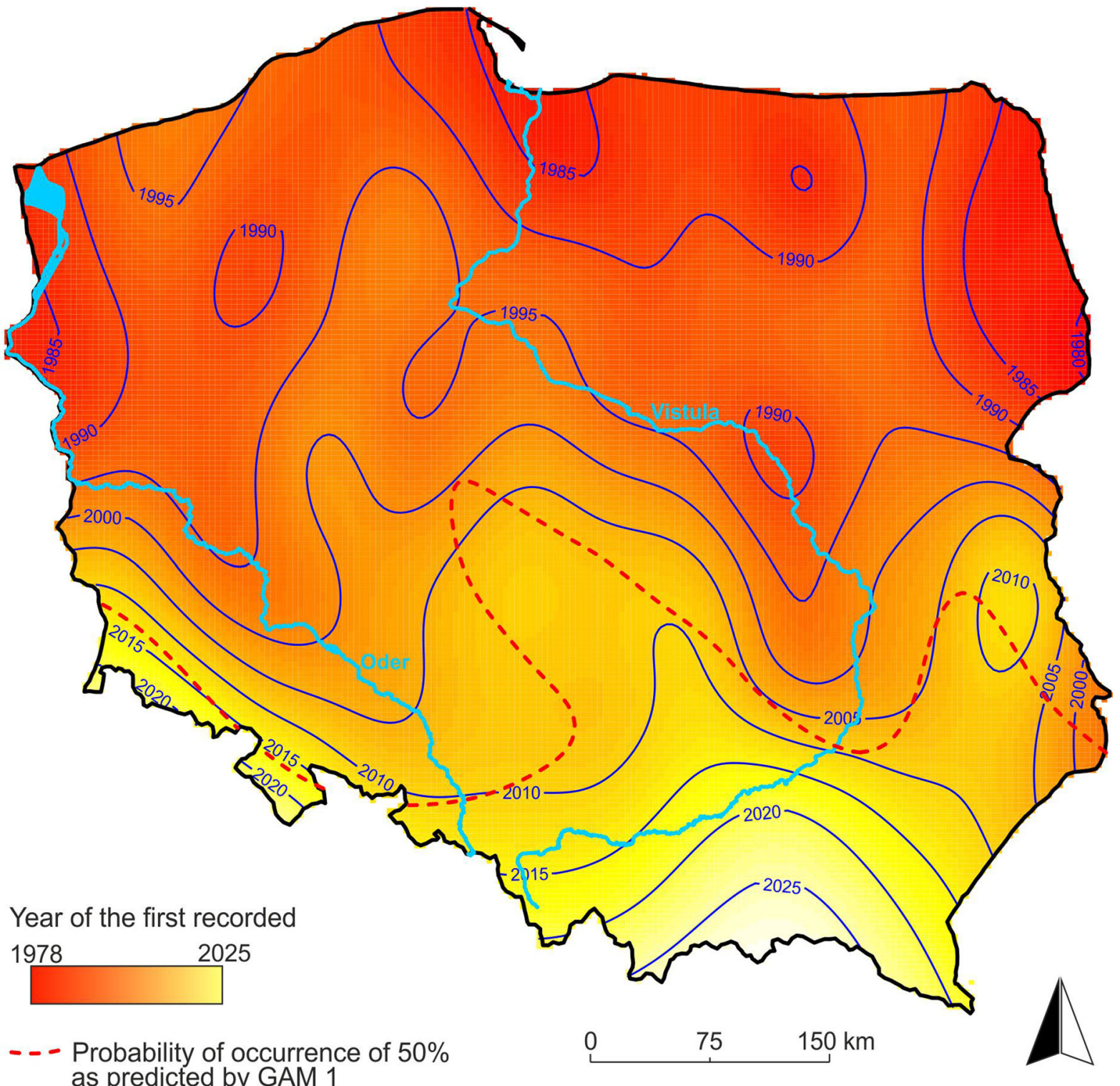

Fig. 2 Year of the first record of American mink as predicted by GAM 2. Probability of occurrence of 50\% based on GAM 1 is marked with a dashed line

\section{Mink densities}

Trapping success varied greatly among sites and years. The highest trapping success was 20 mink/100 trapnights (Fig. 4), and the mean trapping success for all sites where at least one individual was trapped was 7 mink/100 trap-nights. Mink density indices were not related to the types of water-body but were higher in spring than in autumn. Variation in mink density indices over time since local populations were established was better explained by the nonlinear model than by the linear model (Table 1). Density index increased quickly after population establishment and was estimated to be highest in 10-15 year old populations (Fig. 5). In these years the average density index reached almost 7 mink/100 trap-nights in autumn and 9 mink/100 trap-nights in spring. After that period mink density index started to decrease; although the loess curve fitted to the original data 

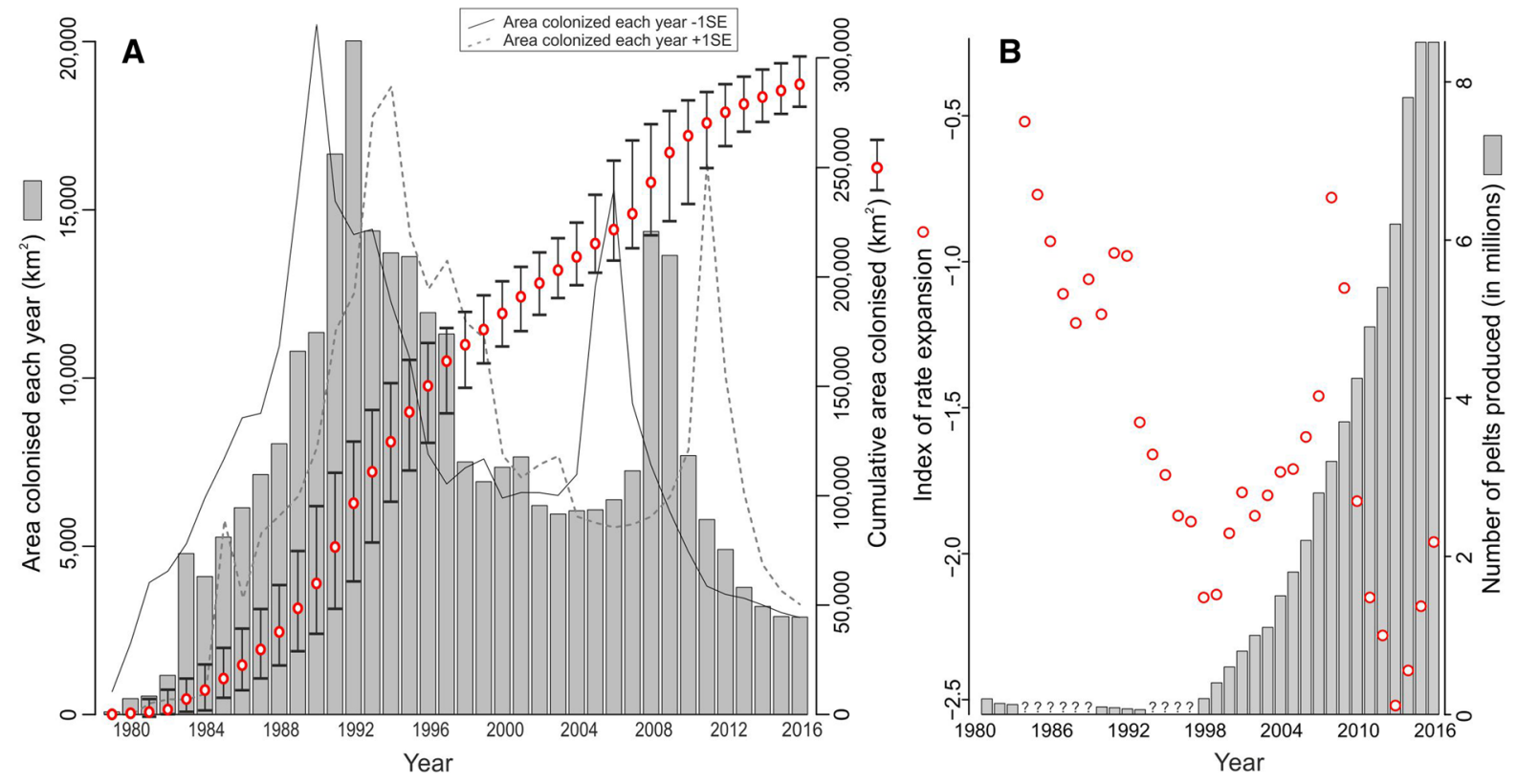

Fig. 3 a Proportion of Poland $\left(312,679 \mathrm{~km}^{2}\right)$ colonised by American mink each year (grey bars accompanied by two lines showing colonisation date $+1 \mathrm{SE}$ and $-1 \mathrm{SE}$ ) and in total (red dots, $\pm \mathrm{SE}$ ) as predicted by the GAM 2 model visualised in Fig. 2. b Index of range expansion (red dots) and number of

suggests that density stabilizes at a level of ca. 5 mink/ 100 trap-nights (Fig. 5).

\section{Discussion}

Mink occurrence in Central and Eastern Europe

This study showed the non-linear expansion of the American mink, both in rate of range expansion and the population density. The rate of range expansion had accelerating and decelerating patterns at various stages of the invasion, which most probably reflects both variation in habitat (especially the share of aquatic habitats within the colonised area) and prey availability in newly colonised areas (Melero et al. 2014; Fraser et al. 2015), and the number of mink that escaped from farms (which is correlated with the number of farms) (Fasola et al. 2011; Iordan et al. 2012). The density of mink in colonised areas increased to a high level during the first stage and then decreased 10-15 years after an area was colonised. After nearly 40 years the expansion is still ongoing. mink pelts produced in Poland per year (in millions, grey bars). Data of pelt production in Poland from: Sławoń (1993), Zalewski and Brzeziński (2014), www.FurEurope. Question mark indicates lack of data

American mink expansion in Poland is a part of a continent-wide process of its invasion in Europe, however, in Central and Eastern European countries the dynamics of mink expansion is not described sufficiently. To the north-east and east of Poland, wild living mink population is widespread in Lithuania, Latvia, Estonia and Belarus (Mickevicius and Baranauskas 1992; Ozolinš̌ and Pilāts 1995; Sidorovich 1997; Bonesi and Palazon 2007). These populations were established until the 1970s. In Ukraine, the first wild living mink were reported in the northern regions of the country in the 1960s and until 2000 mink colonised among others the upper Pripyat river and its tributaries (Panov 2002) but not south-western Ukraine. The few mink records, with no proof of the existence of populations were described in Slovakia and Hungary (Bonesi and Palazon 2007). In Romania, wild living mink have been recorded between 1986 and 2009 in Transylvania (Hegyeli and Kecskés 2014) and they are considered to be farm escapees. In the Czech Republic, wild living mink population originating from farm escapees was still expanding in the 1990s (Cervený and Toman 1999). In Germany, wild living mink are most common and widespread in the 


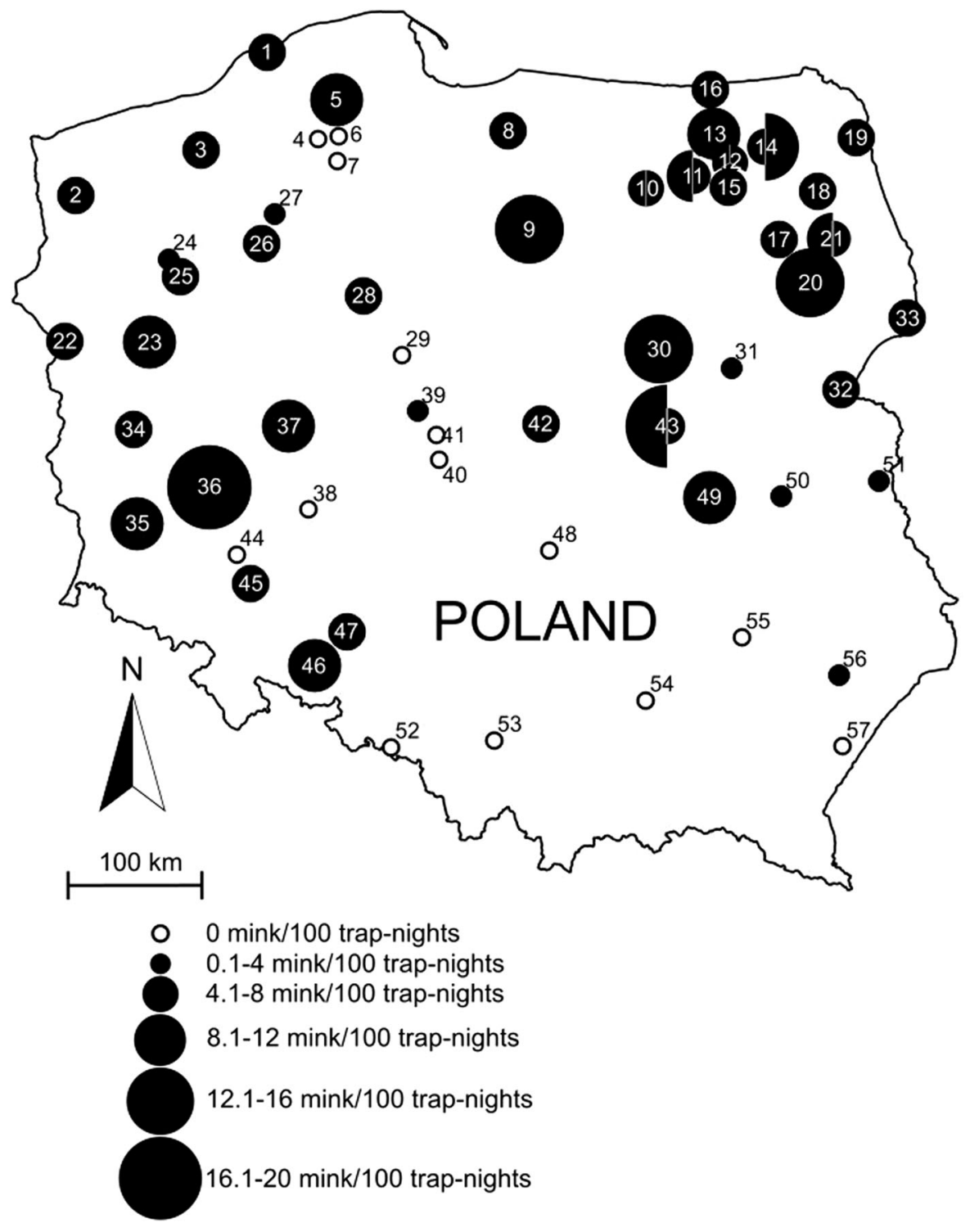

Fig. 4 The location of trapping sites and mink trapping success (number of mink trapped per 100 trap-nights) in Poland. For the sites where mink were trapped in at least two periods, the lowest

east, where the population was increasing since the 1970s (Stubbe 1988; Arnold et al. 2016).

North-eastern Poland was undoubtedly colonised by mink from the east (Belarus, Lithuania, and Russia), where a large mink population has existed since the 1930s (Danilov and Tumanov 1976). The origin of the mink population in north-west Poland is not clear. The first wild living mink were observed just a few years after the first mink records from the northeast, and these could have been escapees from Polish and highest trapping successes are presented. Numbers on the map correspond to study site number from "Appendix 1"

mink farms or immigrants from Germany. The hypothesis that the mink population in Poland originated both from immigrants from the east and escapees from Polish farms is supported by the fact that in the second half of the 1980s wild living mink were observed outside the wave expanding from the north-east or north-west. For example, at that time a local mink population existed near Warsaw (central Poland; Fig. 2), which was probably not connected 
Table 1 Summary of the generalized additive mixed model (GAMM 3) analysing variation of American mink density in 81 sites in relation to habitat type, season and time that has passed since mink colonised the area

\begin{tabular}{lllr}
\hline Explanatory variable & $\mathrm{B}(\mathrm{SE})$ & $\mathrm{t}$ or $\mathrm{F}$ & $p$ value \\
\hline Intercept & $72.95(62.46)$ & $\mathrm{t}=1.2$ & 0.247 \\
Habitat: large river & 0 & & \\
Habitat: medium river & $0.25(1.53)$ & $\mathrm{t}=0.2$ & 0.872 \\
Habitat: small river & $-0.32(1.37)$ & $\mathrm{t}=0.2$ & 0.819 \\
Habitat: lake & $-0.53(1.34)$ & $\mathrm{t}=0.4$ & 0.695 \\
Season: Nov-Dec & 0 & & \\
Season: Jan-Feb & $1.31(1.30)$ & $\mathrm{t}=1.0$ & 0.316 \\
Season: Mar-Apr & $2.88(1.21)$ & $\mathrm{t}=2.4$ & 0.020 \\
Years since colonisation & $d f=2.98$ & $\mathrm{~F}=6.0$ & $<0.001$ \\
$\mathrm{R}_{\text {adj }}^{2}$ & $28.7 \%$ & & \\
\hline
\end{tabular}

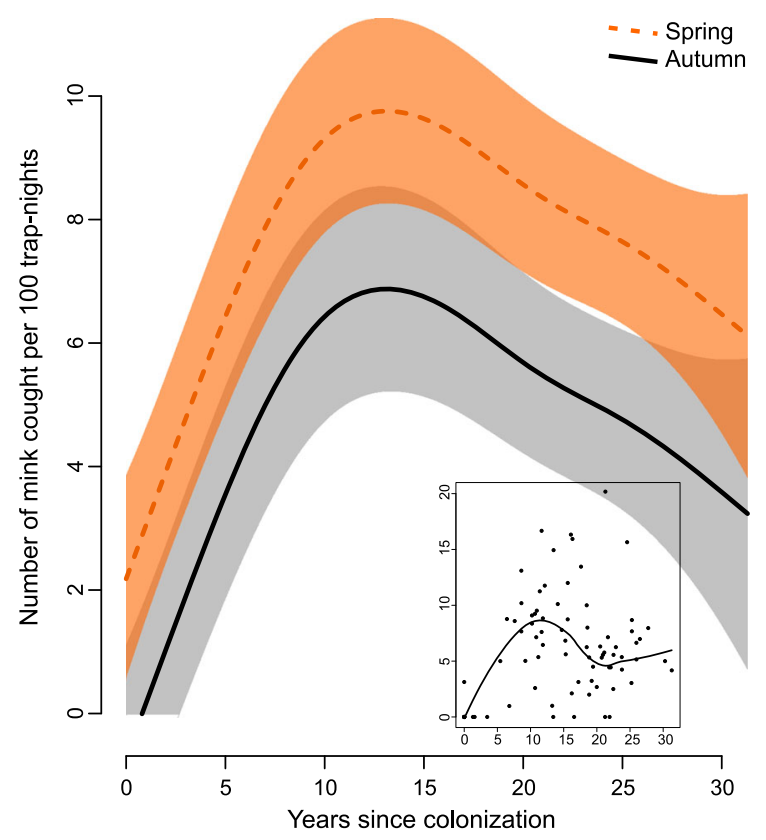

Fig. 5 Variation in mink density as a function of time since colonisation as predicted by GAMM 3 for the spring and autumn period (winter period is not shown to aid clarity). Inner subplot visualizes the original data and loess curve

with the mink population expanding from the northeast prior to 1995 .

Our reconstruction of mink expansion may be biased because of the detection threshold (Lockwood et al. 2013). In the first years of mink invasion hunters and conservationists did not have adequate knowledge about this species. Thus the mink could have remained undetected for substantial periods, especially if its density was low (Clark 1970; Smal 1988). Therefore, the map of the history of mink expansion in Poland is probably "conservative", and mink could have colonised particular regions earlier than we have predicted. It is highly possible that mink are nowadays detected in newly colonised areas more quickly than in the past as the public is now more aware of this species. In colonised territories there are probably still some areas where mink is not abundant due to a sparse network of rivers leading to habitat isolation, but these gaps are difficult to detect. We cannot exclude, however, that some proportion of "zeros" (i.e. questionnaires reporting absences) are false leaving us with a mixture of true absences and undetected presences.

Factors affecting mink range expansion rates

In some non-native invasive species there are lag times between initial introduction and population explosions (Crooks and Soulé 1999). Lag time can vary considerably and is related to many factors, e.g., the number of founder individuals, species dispersal ability and their adaptation to local conditions (Crooks and Soulé 1999; Lockwood et al. 2013). As the mink spreading in Poland partly originated from the established Eastern European population, a time lag was probably not observed in this case.

Despite the lack of a time lag, mink dispersal from invaded territories can last for many decades. For example, Sweden, Norway, and Finland, which are slightly larger than Poland, were colonised by mink during 30-40 years (Gerell 1967; Bevanger and Henriksen 1995; Kauhala 1996). In Poland the rate of expansion by area varied temporally but was always high as compared to rates of range expansion recorded in Scotland (range from 101 to $2866 \mathrm{~km}^{2} /$ year, with a mean of $1327 \mathrm{~km}^{2} /$ year; Fraser et al. 2015), which suggest that some landscape features, especially mountains, may reduce the expansion rate. On the other hand, high density of rivers and lakes per unit area, probably accelerate mink expansion. In the model created by Iordan et al. (2012), predicted value of the rate of range expansion of mink population is about $2 \mathrm{~km} /$ year but the values recorded in other studies were higher and varied from about 2.5 to $22.5 \mathrm{~km} /$ year in Portugal (Rodrigues et al. 2015), from 
5.5 to $9 \mathrm{~km} /$ year in Argentina (Fasola et al. 2011) and up to $27.3 \mathrm{~km} /$ year in Scotland (Fraser et al. 2015).

In Poland, mink expansion pattern showed accelerating and decelerating stages. It reached its maximum 12 years after the beginning of expansion, slowed down over next 15 years, and then again increased between 2008 and 2009. The non-linear rate of range expansion was partly driven by the share of aquatic habitats and thus confirmed that the rate of mink spread is related to river and lake network and landscape heterogeneity (Kauhala 1996; Iordan et al. 2012; Fraser et al. 2015). The pattern of mink spread observed in Poland has been shaped by geographical differences between the northern and southern part of the country. In the north, the postglacial landscape (Last Glacial Maximum) is characterized by lakes and a well-developed network of rivers (many lakes are connected by small water courses). There are about 9300 lakes in Poland larger than 1 ha, and about 90\% of them are concentrated in the north (Kondracki 1988). In the south there are no lakes, but highlands and mountains, which hamper mink movement and dispersal (Zalewski et al. 2009). On the contrary, the share of urban habitats (lower in the north and higher in the south of the country) seems to slow down the expansion because mink avoid human settlements (Brzeziński et al. 2018). As a consequence, the explanation of non-linear range expansion rates can be substantially improved by taking land-use data into account.

As mink dispersal usually occurs along larger water courses (Gerell 1967), faster southwards mink expansion was mainly observed along the valleys of the two main Polish rivers: the Vistula and Oder. Interestingly, we detected one quite large area in northern-central Poland where mink occurrence has not been confirmed, neither by questionnaires nor by trapping and raft monitoring. The mentioned area abounds in lakes and other good quality habitats but it is located near the major drainage divide, which may suggest that due to isolation the wave of mink expansion from the west and/or the east has not reached that area yet. The major drainage divide probably separated the two invasive waves in eastern and western Poland. The different origin of mink in both areas and restricted gene flow has been confirmed (Zalewski et al. 2010). All these suggest that river network connectivity affects the rate of range expansion.
At the beginning of the mink expansion, escapees from farms probably only contributed to the wild living populations in some areas, as the number of farms in Poland was relatively low. At the end of the 1950 s production reached 100,000 pelts per year and 200,000 in 1998 . Mink farming rapidly developed in Poland at the end of the 1990s. In 2011 mink farms produced ca. $5 \mathrm{mln}$ pelts and the number of mink farms was estimated to be 360 (Zalewski and Brzeziński 2014). Nowadays about $80 \%$ of them are in north-western Poland, in three districts covering $18 \%$ of the country. These changes in mink farming began when the feral mink population in Poland was expanding and its range covered approximately about half of the country. The direct effect of the development of mink farming on sustaining the mink expansion is difficult to determine. In Poland, unlike some other European countries, there are no documented mass escapes of mink, and the inflow of farm escapees is probably much lower than for example in Denmark, where escapees constitute $86 \%$ of free ranging mink (Hammersh $\varnothing$ j 2004). However, genetic data explicitly show that in Poland the inflow of ranch mink into wild living populations is still ongoing (Zalewski et al. 2010, 2011).

Multiple introductions can be caused by repeated escapes of animals from farms. The observed increased mink range expansion rate in Poland in the years 2008-2009 may be related to an increased propagule pressure. The development of mink farming after 2000 may have accelerated mink expansion in south-western Poland. Also in other parts of Europe, the establishment and expansion of the wild living mink population have been connected with the development of mink farming (Gerell 1967; Cuthbert 1973; Kauhala 1996). Gerell (1967) suggested that in Sweden the likelihood of mink escaping from farms did not increase in direct proportion to the fast expansion of mink farming in the 1950s. Similar conclusion that reinforcement by periodic escapes from farms does not influence the progress of feral mink populations has come from Scotland (Cuthbert 1973). However, more recent studies have highlighted the importance of the inflow of farm escapees (Zalewski et al. 2010, 2011). 
Variation in mink density during colonisation

The density of non-native species can vary considerably across their invasive range (Hansen et al. 2013) and may be related to the time that has passed since the establishment of their local populations. Booms of invasive species populations at the beginning of the expansion are often followed by crashes (Simberloff and Gibbons 2004) and we described such a pattern in the case of mink density in Poland. The increase in population density of invasive species after their introduction to novel environments is the basic requirement for they spread (Lockwood et al. 2013). The duration and slope of this increase probably depend on many ecological factors. Gerell (1967) stated that in Sweden mink had not yet reached maximum densities 35 years after the beginning of the invasion, whereas in Poland mink reached their maximum densities after 10-15 years. After that period, mink density decreased. Our models did not show a clear stabilization in mink density after the decrease, most likely because the number of trapping sites in areas with mink populations that have existed for 25-30 years was low. However, simple loess model suggests stabilization of mink density on level 5-6 mink per 100 trap-nights after 20 years. In contrast to the boom-bust of invasive species concept, mink population density in Poland decreased over time but the decrease was not as severe as it was described for some birds (Aagaard and Lockwood 2016).

Generally, mink population densities vary spatially according to habitat, and mink populations are most dense in areas with abundant and stable water ecosystems (e.g. eutrophic lakes) (Gerell 1967; Melero et al. 2012). In Poland we did not find any differences in the mink density index among the considered water body types (which may reflect different habitats). Decreases in mink density may be related to numerous ecological factors, for example: to increases in negative interactions with top predators, like the otter Lutra lutra or the red fox Vulpes vulpes (McDonald et al. 2007; Carlsson et al. 2010) or to an over exploitation of prey by invasive species and in consequence decrease in food availability. Indeed, a short time after colonisation of a new area the abundance of some prey (e.g. water birds and water vole) and its proportion in the mink diet decreased (Macdonald et al. 2002; Sidorovich et al. 2010; Brzeziński et al. 2012; Zalewski and
Bartoszewicz 2012). At the beginning of expansion in Poland, mink may have benefited from the abundance of the introduced muskrat Ondatra zibethicus, which is an important prey of mink in its native range (Errington 1943). Before mink invasion, muskrats were very numerous in various aquatic habitats (Brzeziński et al. 2010) providing mink in newly colonised areas with profitable prey. They became, however, intensively hunted by mink in the initial stage of the mink invasion (Bartoszewicz and Zalewski 2003), and since the 1990s the muskrat population has declined due to heavy mink predation and/or other environmental factors (Brzeziński et al. 2010). As a consequence, a lack of this prey could have contributed to the slower range expansion in 1990-2000. Similarly, in Spain the density of the introduced mink population was related to the abundance of invasive crayfish (Melero et al. 2014).

Another factor that could affect mink density after the 15-year long expansion is management by humans. Intensive mink hunting or culling can lower its densities (Melero et al. 2010; Bryce et al. 2011). In Poland, American mink was added to the game list in 2001. Hunting bags increased up to ca. 3000 individuals per year during the first three hunting seasons and reached 4200 individuals in 2014/2015 (Skorupski 2016). However, mink hunting bags in Poland are still relatively low. For example in Denmark, which is sevenfold smaller than Poland, the annual mink bag at the beginning of the 2000s was about 8000 (Hammershøj 2004). Therefore, hunting pressure was probably too low to reduce the mink population in Poland substantially. Increased mortality or reduction of fitness can also be caused by accumulation of pathogens (e.g. parasites). The recent study showed that parasite abundance in invasive mink significantly increased over successive years after introduction (Kołodziej-Sobocińska et al. 2018). Therefore, accumulation of parasites and other pathogens may decrease the density of mink populations and explains the non-linear change of mink population density in a colonised area.

\section{Conclusions}

Our results have shown that mink expansion can have an accelerating and decelerating pattern, and acceleration of the invasion rate may occur many times during 
an invasion. The factors that probably accelerate the invasion rate are availability and connectivity of suitable aquatic habitats, but also an increase in propagule pressure of the invasive species. The nonlinear pattern of mink population density in a colonised area suggests that up to 10 years after invasion, mink populations reach high densities and therefore this period may be critical for prey survival. It is likely that conservation measures applied during this period would be of high importance for mitigating the negative impact of the invasive predator on its prey. On the other hand, the mink population decrease following the density peak, provides prey with the opportunity to recover. The process of recovery, however, is often accompanied by habitat shifts and behavioural adaptations in prey populations to reduce spatio-temporal overlap with the new predator (Brzeziński et al. 2012, 2018). It is important therefore that habitat management and conservation measures are adjusted to the new spatial distributions of prey populations, and proper prediction of non-native species invasion rates and population dynamics should be incorporated into management actions curbing the negative impact of an invasive species.

Acknowledgements We thank E. Bujko, P. Chibowski, R. Dąbrowska, M. Karolewski, E. Komar, M. Marzec, A. Mohr, A. Niemczynowicz, G. Osojca, M. Pilot, Ł. Rodak, M. Śmielak, M. Zegarek for help with mink trapping and T. Diserens for improving English. This study was financed by the National Science Centre, Poland (Grant No: 2013/09/B/NZ8/03339).

Open Access This article is distributed under the terms of the Creative Commons Attribution 4.0 International License (http:// creativecommons.org/licenses/by/4.0/), which permits unrestricted use, distribution, and reproduction in any medium, provided you give appropriate credit to the original author(s) and the source, provide a link to the Creative Commons license, and indicate if changes were made.

\section{Appendix}

See Table 2.

Table 2 Names and coordinates of rivers and lakes where mink were trapped

\begin{tabular}{|c|c|c|c|c|}
\hline No. & Name & Year & $\mathrm{N}$ & $\mathrm{E}$ \\
\hline 1 & Modła Lake & 2016 & 55.550758 & 16.789953 \\
\hline 2 & Ina River & 2015 & 53.555868 & 14.733143 \\
\hline 3 & Parsęta River & 2016 & 53.893606 & 16.091527 \\
\hline 4 & Trzebielsk Lake & 2015 & 53.992383 & 17.388845 \\
\hline 5 & Słupia River & 2006 & 54.250051 & 17.583284 \\
\hline 6 & Somińskie Lake & 2016 & 54.007160 & 17.623197 \\
\hline 7 & Brda River & 2015 & 53.844141 & 17.610145 \\
\hline 8 & Drużno Lake & 2013 & 54.052088 & 19.517329 \\
\hline 9 & Wel River & 2006 & 53.402645 & 19.735784 \\
\hline 10 & Majcz Wielki Lake & 1996-1997 & 53.779425 & 21.455385 \\
\hline 11 & Inulec Lake & 1997-2007 & 53.805460 & 21.481221 \\
\hline 12 & Łuknajno Lake & 1996-2012 & 53.802782 & 21.635319 \\
\hline 13 & Jagodne Lake & 2004 & 53.945755 & 21.744666 \\
\hline 14 & Tuchlin Lake & 1996-2006 & 53.797206 & 21.769987 \\
\hline 15 & Kociołek Lake & 1995-1996 & 53.720201 & 21.858864 \\
\hline 16 & Węgorapa River & 2014 & 54.296558 & 21.783884 \\
\hline 17 & Biebrza River & 2009-2010 & 53.287774 & 22.467324 \\
\hline 18 & Biebrza River & 2009-2011 & 53.590165 & 22.930429 \\
\hline 19 & Czarna Hańcza River & 2014 & 53.928522 & 23.378325 \\
\hline 20 & Narew River & 2010-2011 & 53.084518 & 22.815968 \\
\hline 21 & Narew River & 2009-2015 & 53.224027 & 22.845425 \\
\hline 22 & Warta River & 2009-2010 & 52.594231 & 14.713224 \\
\hline
\end{tabular}


Table 2 continued

\begin{tabular}{|c|c|c|c|c|}
\hline No. & Name & Year & $\mathrm{N}$ & $\mathrm{E}$ \\
\hline 23 & Warta River & 2010-2011 & 52.615960 & 15.627416 \\
\hline 24 & Drawa River & 2009-2011 & 53.170834 & 15.794675 \\
\hline 25 & Drawa River & 2009-2010 & 53.058682 & 15.933420 \\
\hline 26 & Gwda River & 2007 & 53.289821 & 16.801316 \\
\hline 27 & Gwda River & 2015 & 53.489262 & 16.937580 \\
\hline 28 & Noteć River & 2016 & 52.967056 & 17.931850 \\
\hline 29 & Gopło Lake & 2013 & 52.577686 & 18.350504 \\
\hline 30 & Narew River & 2004 & 52.600150 & 21.125983 \\
\hline 31 & Liwiec River & 2014 & 52.463097 & 21.890495 \\
\hline 32 & Bug River & 2016 & 52.284959 & 23.053919 \\
\hline 33 & Narewka River & 2001-2002 & 52.723892 & 23.819787 \\
\hline 34 & Odra River & 2016 & 52.041033 & 15.498411 \\
\hline 35 & Bóbr River & 2016 & 51.426125 & 15.584631 \\
\hline 36 & Barycz River & 2016 & 51.687090 & 16.328062 \\
\hline 37 & Warta River & 2013 & 52.099315 & 17.152136 \\
\hline 38 & Milicz Ponds & 2005 & 51.554724 & 17.383948 \\
\hline 39 & Warta River & 2012 & 52.209886 & 18.519788 \\
\hline 40 & Warta River & 2015 & 51.898411 & 18.752472 \\
\hline 41 & Warta River & 2006 & 52.054237 & 18.721597 \\
\hline 42 & Bzura River & 2015 & 52.126237 & 19.835992 \\
\hline 43 & Wisła River & 2005-2011 & 52.123246 & 21.179569 \\
\hline 44 & Odra River & 2012 & 51.247887 & 16.635597 \\
\hline 45 & Bystrzyca River & 2016 & 51.059461 & 16.796817 \\
\hline 46 & Nysa Kłodzka River & 2016 & 50.529244 & 17.470159 \\
\hline 47 & Odra River & 2016 & 50.760125 & 17.800092 \\
\hline 48 & Pilica River & 2015 & 51.294740 & 19.906652 \\
\hline 49 & Wisła River & 2007 & 51.619424 & 21.608352 \\
\hline 50 & Wieprz River & 2015 & 51.602534 & 22.369302 \\
\hline 51 & Hanna River & 2015 & 51.673116 & 23.400472 \\
\hline 52 & Odra River & 2014 & 50.004707 & 18.276902 \\
\hline 53 & Wisła River & 2014 & 50.050522 & 19.319898 \\
\hline 54 & Wisła River & 2014 & 50.299438 & 20.885086 \\
\hline 55 & San River & 2007 & 50.692172 & 21.894179 \\
\hline 56 & Tanew River & 2015 & 50.414645 & 22.871712 \\
\hline 57 & San River & 2015 & 49.945044 & 22.873268 \\
\hline
\end{tabular}

\section{References}

Aagaard K, Lockwood JL (2016) Severe and rapid population declines in exotic birds. Biol Invasions 18:1667-1678

Arim M, Abades SR, Neil PE, Lima M, Marquet PA (2006) Spread dynamics of invasive species. PNAS 103:374-378 Arnold JM, Greiser G, Krüger S, Martin I (2016) Status und Entwicklung ausgewählter Wildtierarten in Deutschland. Jahresbericht 2015. Wildtier-Informationssystem der
Länder Deutschlands (WILD). Deutscher Jagdverband (Hrsg.), Berlin (in German)

Bartoszewicz M, Zalewski A (2003) American mink, Mustela vison diet and predation on waterfowl in the Słońsk Reserve, western Poland. Folia Zool 52:225-238

Bevanger K, Henriksen G (1995) The distributional history and present status of the American mink (Mustela vison Schreber, 1777) in Norway. Ann Zool Fenn 32:11-14

Bonesi L, Palazon S (2007) The American mink in Europe: status, impacts, and control. Biol Conserv 134:470-483 
Bryce R, Oliver MK, Davies L, Gray H, Urquhart J, Lambin X (2011) Turning back the tide of American mink invasion at an unprecedented scale through community participation and adaptive management. Biol Conserv 144:575-583

Brzeziński M, Marzec M (2003) The origin, dispersal and distribution of the American mink Mustela vison in Poland. Acta Theriol 48:505-514

Brzeziński M, Romanowski J, Żmihorski M, Karpowicz K (2010) Muskrat (Ondatra zibethicus) decline after the expansion of American mink (Neovison vison) in Poland. Eur J Wildl Res 56:341-348

Brzeziński M, Natorff M, Zalewski A, Żmihorski M (2012) Numerical and behavioral responses of waterfowl to the invasive American mink: a conservation paradox. Biol Conserv 147:68-78

Brzeziński M, Ignatiuk P, Żmihorski M, Zalewski A (2018) An invasive predator affects habitat use by native prey: American mink and water vole co-existence in riparian habitats. J Zool 304:109-116. https://doi.org/10.1111/jzo. 12500

Carlsson NOL, Jeschke JM, Holmqvist N, Kindberg J (2010) Long-term data on invaders: when the fox is away, the mink will play. Biol Invasions 12:633-641

Cervený J, Toman A (1999) New findings of the American mink (Mustela vison) in south-western part of the Czech Republic. Lynx 30:27-34

Clark SP (1970) Field experience of feral mink in Yorkshire and Lancashire. Mammal Rev 1:41-47

Clavero M, García-Berthou E (2005) Invasive species are leading cause of animal extinctions. Trends Ecol Evol 20:110

Crooks JA, Soulé ME (1999) Lag times in population explosions of invasive species: causes and implications. In: Snadlund OT, Schei PJ, Viken A (eds) Invasive species and biodiversity management. Kluwer Academic Publishers, Dordrecht, pp 103-125

Cuthbert JH (1973) The origin and distribution of feral mink in Scotland. Mamm Rev 3:97-103

Danilov PI, Tumanov IL (1976) Mustelids of the north-west of the USSR. Nauka, Leningrad (in Russian)

Errington P (1943) Muskrat populations. The Iowa State University Press, Iowa

Fasola L, Muzio J, Chehébar C, Cassino M, Macdonald DW (2011) Range expansion and prey use of American mink in Argentinean Patagonia: dilemmas for conservation. Eur J Wild Res 57:283-294

Fraser EJ, Lambin X, Travis JMJ et al (2015) Range expansion of an invasive species through a heterogeneous landscape-the case of American mink in Scotland. Divers Distrib 21:888-900

Gerell R (1967) Dispersal and acclimatization of the mink (Mustela vison Schreber) in Sweden. Viltrevy 5:1-38

Hammershøj M (2004) Population ecology of free-ranging American mink Mustela vison in Denmark. Ph.D. thesis, National Environmental Research Institute, Kalø, Denmark, pp 1-30

Hansen GJA, Vander Zanden MJ, Blum MJ, Clayton MK, Hain EF et al (2013) Commonly rare and rarely common: comparing population abundance of invasive and native aquatic species. PLoS ONE 8(10):e77415
Hastings A, Cuddington K, Davies KF et al (2005) The spatial spread of invasions: new developments in theory and evidence. Ecol Lett 8:91-101

Hegyeli Z, Kecskés A (2014) The occurrence of wild-living American Mink Neovison vison in Transylvania, Romania. Small Carnivore Conserv 51:23-28

Hilton GM, Cuthbert RJ (2010) The catastrophic impact of invasive mammalian predators on birds of the UK overseas territories: a review and synthesis. Ibis 152:443-458

Iordan F, Rushton SP, Macdonald DW, Bonesi L (2012) Predicting the spread of feral populations of the American mink in Italy: Is it too late for eradication? Biol Invasions 14:1895-1908

Kauhala K (1996) Distributional history of the American mink (Mustela vison) in Finland with special reference to the trends in otter (Lutra lutra) populations. Ann Zool Fenn 33:283-291

Kołodziej-Sobocińska M, Brzeziński M, Niemczynowicz A, Zalewski A (2018) High parasite infection level in nonnative invasive species: it is just a matter of time. Ecography 41:1283-1294. https://doi.org/10.1111/ecog.03362

Kondracki J (1988) Physical geography of Poland. PWN, Warszawa (in Polish)

Lisiecki H, Sławoń J (1980) Hodowla norek. Państwowe Wydawnictwa Rolnicze i Leśne, Warszawa (in Polish)

Lockwood JL, Hoopes MF, Marchetti MP (2013) Invasion ecology. Wiley, New York

Macdonald DW, Sidorovich VE, Anisomova EI, Sidorovich NV, Johnson PJ (2002) The impact of American mink Mustela vison and European mink Mustela lutreola on water voles Arvicola terrestris in Belarus. Ecography 25:295-302

McDonald RA, O'Hara K, Morrish DJ (2007) Decline of invasive alien mink (Mustela vison) is concurrent with recovery of native otters (Lutra lutra). Divers Distrib 13:92-98

Melero Y, Palazon S, Bonesi L, Gosalbez J (2010) Relative abundance of culled and not culled American mink populations in northeast Spain and their potential distribution: Are culling campaigns effective? Biol Invasions 12:3877-3885

Melero Y, Plaza M, Santulli G et al (2012) Evaluating the effect of American mink, an alien invasive species, on the abundance of a native community: Is coexistence possible? Biodivers Conserv 21:1795-1809

Melero Y, Palazon S, Lambin X (2014) Invasive crayfish reduce food limitation of alien American mink and increase their resilience to control. Oecologia 174:427-434

Mickevicius E, Baranauskas K (1992) Status, abundance and distribution of mustelids in Lithuania. Small Carnivore Conserv 6:11-14

Okubo A, Levin SA (2002) Diffusion and ecological problems: modern perspective. Springer, New York

Ozoliņš J, Pilāts V (1995) Distribution and status of small and medium-sized carnivores in Latvia. Ann Zool Fenn 32:21-29

Panov G (2002) Dynamics of ranges and of abundances of semiwater fur-bearing mammals in Ukraine during second part of the 20th century. Visnyk of L'viv Univ 30:119-132 (in Ukrainian) 
R Core Team (2016) R: A language and environment for statistical computing. R Foundation for Statistical Computing, Vienna, Austria. http://www.R-project.org/

Reeves SA, Usher MB (1989) Application of a diffusion model to the spread of an invasive species: the coypu in Great Britain. Ecol Model 47:217-232

Rodrigues DC, Simões L, Mullins J et al (2015) Tracking the expansion of the American mink (Neovison vison) range in NW Portugal. Biol Invasions 17:13-22

Romanowski J, Kaszuba S, Koźniewski P (1984) New data on the occurrence of minks (Mammalia: Mustelidae) in Poland. Przegl Zool 28:221-223 (in Polish with English summary)

Ruiz-Olmo J, Palazon S, Bueno F, Bravo C, Munilla I, Romero R (1997) Distribution, status and colonization of the American mink Mustela vison in Spain. J Wildl Res $1: 30-36$

Ruprecht AL (1996) Materials to the distribution of the members of subgenus Lutreola Wagner, 1841 (Carnivora: Mustelidae) in Poland. Przegl Zool 40:223-233 (in Polish with English summary)

Ruprecht AL, Buchalczyk T, Wójcik JM (1983) The occurrence of minks (Mammalia: Mustelidae) in Poland. Przegl Zool 27:87-99 (in Polish with English summary)

Sidorovich VE (1997) Mustelids in Belarus. Zolotoy uley, Minsk

Sidorovich VA, Polozov AG, Zalewski A (2010) Food niche variation of European and American mink during the American mink invasion in north-eastern Belarus. Biol Invasions 12:2207-2217

Simberloff D, Gibbons L (2004) Now you see them, now you don't!-population crashes of established introduced species. Biol Invasions 6:161-172

Skellam JG (1951) Random dispersal in theoretical populations. Biometrika 38:196-218

Skorupski J (2016) Biological invasions and expansions of carnivorans in Poland. Studia i Materiały CEPL w Rogowie 18(49A/4):58-72 (in Polish with English summary)
Sławoń J (1993) Aktualna sytuacja w hodowli mięsożernych zwierząt futerkowych. Zeszyty Naukowe Przegląd Hodowlany 12:69-77 (in Polish)

Smal CM (1988) The American mink Mustela vison in Ireland. Mamm Rev 18:201-208

Smith DL, Lucey B, Waller LA et al (2002) Predicting the spatial dynamics of rabies epidemics on heterogeneous landscapes. PNAS 99:3668-3672

Stubbe M (1988) Die expansive Arealerweiterung des Minks Mustela vison (Schreber, 1777) in der DDR in den Jahren 1975 bis 1984. Beitr Jagd- u Wildforsch 15:69-75 (in German)

Wood SN (2006) Generalized additive models: an introduction with R. Chapman and Hall, Boca Raton

Zalewski A, Bartoszewicz M (2012) Phenotypic variation of an alien species in a new environment: the body size and diet of American mink over time and at local and continental scales. Biol J Linn Soc 105:681-693

Zalewski A, Brzeziński M (2014) Norka amerykańska. Biologia gatunku inwazyjnego. Instytut Biologii Ssaków PAN, Białowieża (in Polish)

Zalewski A, Piertney SB, Zalewska H, Lambin X (2009) Landscape barriers reduce gene flow in an invasive carnivore: geographical and local genetic structure of American mink in Scotland. Mol Ecol 18:1601-1615

Zalewski A, Michalska-Parda A, Bartoszewicz M, Kozakiewicz M, Brzeziński M (2010) Multiple introductions determine the genetic structure of an invasive species population: American mink Neovison vison in Poland. Biol Conserv 143:1355-1363

Zalewski A, Michalska-Parda A, Ratkiewicz M, Kozakiewicz M, Bartoszewicz M, Brzeziński M (2011) High mitochondrial DNA diversity of an introduced alien carnivore: comparison of feral and ranch American mink Neovison vison in Poland. Divers Distrib 17:757-768

Żurowski W, Kammler J (1987) American mink (Mustela vison Schreber, 1777) in beaver's site. Przegl Zool 31:513-521 (in Polish with English summary) 